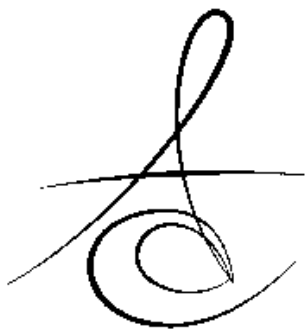

Makale Kodu/Article code: 2248

Makale Gönderilme tarihi: 20.04.2015

Kabul Tarihi: 11.06.2015

\section{TİTANTUM VE ÖZELLİKLERİ}

\section{TITANIUM AND THE PROPERTIES OF TITANIUM}

\author{
Doç. Dr. Perihan OYAR*
}

\section{ÖZET}

Titanyum ilk olarak havacılık endüstrisinde kullanılmıştır. Daha sonraki dönemlerde ise biyolojik uyumluluğu, kolayca şekillendirilmesi ve lehimlenmesi, korozyona direnci ile medikal ve dental alanda geniş bir kullanım alanı bulmuştur. Bu makalede diş hekimliğinde titanyum, titanyumun özellikleri ve uygulamaları hakkında genel bilgi veren bir literatür taraması yapılmıştır.

Anahtar kelimeler: titanyum, titanyum özellikleri, dental uygulamalar

\section{ABSTRACT}

Titanium has been used first in aviation industry. In later periods, biological compatibility, easy shaping, soldering and resistance to corrosion of titanium has found a wide range of applications in the medical and dental fields. In this article, a literature search was conducted related to general information about the features, dental applications of titanium and titanium in dentistry.

Key words: titanium, features of titanium, dental application
Titanyum yer kabuğunda bulunan elementlerin \%0.6' sını oluşturan elementtir. Doğada genellikle rutile $\left(\mathrm{TiO}_{2}\right)$ ya da ilmenit $(\mathrm{FeTiO})$ formunda bulunan bu element, 1789 da William McGregor tarafından bulunmuştur. \%98-99' luk saf titanyum ilk olarak 1910 yılında Hunter' in tarafından elde edilmiştir. ${ }^{1}$

Titanyumunun oksijen, nitrojen hidrojen ile kolaylıkla reaksiyona girmesi metalik olarak bulunmasını olanaksız hale getirir ve genellikle mineraller ile bileşim halinde bulunur. ${ }^{2,3}$

\section{Titanyumun elde edilmesi}

Titanyumun üretimi Kroll işlemi ile yapılır. Kroll metodu; $\mathrm{TiCl}_{4}$ 'ün magnezyum ile indirgenmesi esasına dayanmaktadır. $\mathrm{Bu}$ işlemde titanyumdioksit ve karbon, klor buharı içinde 500 dereceye kadar ısıtılır. Elde edilen ürün titanyum tetraklorid üretimi için bakır tozu ile arındırılır. Titanyumtetrakloritin magnezyum ile reaksiyonundan bir sonraki aşamayı oluşturur. ${ }^{4}$

\section{Atomik özellikleri}

Titanyum bir geçiş elementidir, atom numarası 22' dir ve atomik ağırlığı 47.88' dur. Periyodik tablonun IV A grubundadır ve yoğunluğu $4.51 \mathrm{~g} / \mathrm{cm}^{3 \prime}{ }^{\prime} u ̈ r . r^{5-7}$
Titanyum da birçok metalde olduğu gibi poliformik dönüşümler göstermektedir. Saf titanyum ve alaşımları düşük sıcaklılarda hekzagonal yapıya sahiptirler ve alfa titanyum olarak isimlendirilirler. ${ }^{8}$ Titanyum $882.5{ }^{\circ} \mathrm{C}$ de $\left(1625{ }^{\circ} \mathrm{F}\right)$ yüksek mekanik dayanıkıı̆ı̆a ve iyi şekil verilebilirlik özelliklerindeki hegzagonal alfa fazındayken, bu sıcaklığın üzerinde hacim merkezli kübik yapıdaki beta fazına döner ${ }^{5}$ ve bu form soğuma sırasında da korunur. Beta formdan alfa forma geçiş çok yavaş olmaktadır. Yalnızca çok düşük ısıda bu geçiş hızlanabilir. ${ }^{1,9} 882.5^{\circ} \mathrm{C}^{\prime}$ de alfa fazından beta fazına geçer ve bu fazda $1668{ }^{\circ} \mathrm{C}^{\prime}$ de eriyene kadar kalır. Alfa fazında titanyum, yumuşak ve şekil verilebilirdir. Beta fazında sert, dayanıklı ve şekil verilebilirliliği zordur. Alüminyum, zirkonyum, karbon, oksijen, azot gibi elementlerin titanyuma ilavesi ile yüksek sıcaklıkta bir performans oluşturulur. Bunlar alfa stabilizan elementlerdir. Molibden (Mo), vanadyum (V), tantalyum ( $\mathrm{Ta})$, demir (Fe), krom ( $\mathrm{Cr}$ ) ve kobalt (Co) gibi elementler ise beta stabilizan elementlerdir. Beta fazındaki titanyum kolayca şekillendirilebilir, sıcak ve soğuğa karşı direnç kazanır. 5,10

* Hacettepe Üniversitesi, Sağılı Hizmetleri Meslek Yüksekokulu, Diş-Protez Teknolojisi Programı 
Titanyum çok hafif bir metaldir. $X$ ışını absorbsiyonu nispeten azdır. Erime noktası $1668{ }^{\circ} \mathrm{C}$ $\left(3135{ }^{\circ} \mathrm{C}\right.$ ), kaynama noktası $3260{ }^{\circ} \mathrm{C}$ dir..$^{5,6}$ Titanyum ISI iletkenliği düşük metallerden birisidir ve $20-25{ }^{\circ} \mathrm{C}$ de 21.4 (w/m.K), $15{ }^{\circ} \mathrm{C}$ de $8.35 \times 10^{-6}$ dir. Titanyumun genleşme katsayısı $9.1 \times 10^{-6} /{ }^{\circ} \mathrm{C}$. Titanyum kötü bir elektrik iletkenidir. ${ }^{5,6}$ Titanyumun magnetik alandan etkilenimi çok düşüktür ve bu özelliği ile magnezyum, alüminyum ve paslanmaz çeliklere benzerlik göstermektedir. ${ }^{5-7}$

Hegzagonal kristal yapıdaki metaller kırılgan olmasına rağmen saf titanyum iyi şekillendirilebilir özelliktedir. Titanyumun şekillendirilebilirliliği oksijen, nitrojen ve hidrojen gibi çözünebilen gaz türlerinden kolayca etkilenmektedir. ${ }^{11}$

\section{Kimyasal özellikleri}

Oksijen içerikleri farklılık gösteren dört tip saf titanyum bulunur. ${ }^{12}$ En fazla oksijen içereni $\% 4$ ile Tip 4 tür. Titanyum tipleri arasında içeriklerinde bulunan nitrojen ve demir oranları açısından belirgin farklar gözlenmez. Minör elementlerin oranlarındaki ufak değişiklikler alaşımların fiziksel ve kimyasal özelliklerini belirgin biçimde değişebilir. ${ }^{13}$

Alfa titanyum veya saf titanyum, Alman ve Amerikan standartlarına göre dört sınıfta ayrılmıştır. Ti$1\left(0.15 \mathrm{Fe} ; 0.12 \mathrm{O}_{2}\right), \mathrm{Ti}-2\left(0.20 \mathrm{Fe} ; 0.18 \mathrm{O}_{2}\right), \mathrm{Ti}-3$ $\left(0.25 \mathrm{Fe} ; 0.25 \mathrm{O}_{2}\right), \mathrm{Ti}-4\left(0.30 \mathrm{Fe} ; 0.35 \mathrm{O}_{2}\right)$. Sinıf sayıSI büyüdükçe demir ve oksijen miktarı artar. Saf titanyuma az miktarda karbon, azot, oksijen ve demir katıması belirgin derecede mekanik özellikleri geliştirmektedir. Oksijen miktarının değişmesi metalin elastik modülünü değiştirmektedir. Oksijen miktarının artışı, metalin akma dayanıklılığı ve sertliğini arttııır, uzamayı azaltır. Az miktarda oksijen, demir veya vanadyumun metale eklenmesi, sertliği ve direnci arttırmaktadır. Oksijen veya azotun katılması ile çekme direnci ve esneklik sınırı artar, darbe direnci ise azalır, oksijen içeriğinin artmasıyla ise şekillendirilmesi daha zorlaşmaktadır. ${ }^{5,6,14-16}$

Saf titanyumuna en çok azotun, daha sonra sırasıyla oksijen, karbon ve hidrojenin katılması, sertliğini artırmaktadır. Azot aynı miktardaki oksijen ile kıyaslandığında metalin sertliğini daha çok artırmakta ve metali daha kırılgan hale getirmektedir., ${ }^{5,6,14-16}$

Titanyum $\mathrm{TiO}, \mathrm{TiO}_{2}, \mathrm{Ti}_{2} \mathrm{O}_{3}, \mathrm{Ti}_{3} \mathrm{O}_{5}$ gibi çeşitli formlarda oksit oluşturabilir ve bu oksitlerin tabaka yapıları oldukça komplikedir. En dıştaki oksit tabaka daima oksijenden zengin titanyum dioksittir. Titanyumun etrafındaki oksit tabakası, bu metal alaşımın bakteriostatik özelliğini de açıklamaktadır. ${ }^{1,17}$

Titanyumun oksijene olan afinitesi metal yüzeyinde bir pasifizasyon tabakası oluşumuna sebep olmakta ve $800{ }^{\circ} C^{\prime}$ nin üzerinde pasifizasyon tabakasına göre daha kalın, sert ve kırılgan olan kontaminasyon tabakası oluşmaktadır. ${ }^{18}$ Oksijen konsantrasyonunun \%5-13 arasında bulunduğu durumlarda beta/ alfa allotropik geçiş fazı kaybolmakta ve tüm sıcaklarda titanyum alfa-monofaza dönmektedir. Bu kontaminasyon tabakasına "a-case" adı verilmektedir. a-case' in kompozisyonunda, revetmandan kaynaklanan silisyum ve fosfat ve döküm atmosferinden kaynaklanan karbon, oksijen, hidrojen, azot gibi elementler bulunabilir. a-case tabakas ıluşması istenmeyen bir tabakadır ve materyalin gerilme direnci ve şekil verilebilirliliğini azaltır. ${ }^{5,18}$

Alfa-case tabakasının kalınlığını azaltmak için, revetmanın kimyasal yapısında titanyuma reaktivitesi az oksitlerin kullanılması ve dökümün inert ortamlarda yapılması rutin olarak uygulanan yöntemlerdir. ${ }^{19}$ Ayrıca saf titanyumun içine ilave edilecek elementlerle erime derecesinin düşürülmesi bu tabakanın azalması için kullanılan diğer bir yöntemdir ve dökümün mekanik direncini azaltan iç pörözitelere neden olduğu için tercih edilmemektedir. ${ }^{5,20}$

Titanyumun nitrojen ile olan reaksiyonu oksijen ile olan reaksiyonuna benzerdir. Titanyumun hidrojen gazı ile de reaksiyona girer. Oda sıcaklığının biraz üzerindeki bir sıcaklıkta $1 \mathrm{gr}$ titanyum $400 \mathrm{cc}$ gaz absorbe edebilir ve yüksek sıcakliklarda $\mathrm{CO}_{2}$ absorbe edebilir ve bunun sonucu olarak da karbid ve oksit formu oluşabilmektedir.

Hidroklorik asit ve sülfirik asit titanyum ile oda sıcaklğında hızla reaksiyona girmektedir. Titanyumunun fosforik asit ve nitrik asitle olan etkileşimi ise daha azdır. ${ }^{5}$ Titanyumun flor içeren ajanlarla uzun süre muamele edilmesinin oksit tabakası için sakıncalı olduğu ifade edilmiştir. ${ }^{5}$ Titanyum yüzeyinde oluşan oksit tabakası statik şartlarda, materyale mükemmel bir korozyon direnci sağlamaktadır. ${ }^{5,21}$

Yapılan çalışmalarda titanyumun asit florid ajanlara karşı düşük direnç gösterdiği ve plak akümilasyonunu arttırdığı bulunmuştur. Yapılacak restorasyona göre titanyum metalinin seçiminde mekanik özellikler önem kazanmaktadır. Sabit restorasyonlar için Ti 1 ve Ti 2 derecelerindeki titanyum daha çok

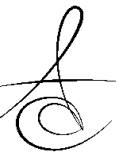


tercih edilmektedir ve Ti 4 derecedeki titanyum metalinin kullanımı ise iskelet bölümlü protezlerde metal alt yapı olarak tavsiye edilmektedir. ${ }^{21}$

\section{Mekanik özellikleri}

Saf titanyumun çekme dayanıklılığı yaklaşık 250 MPa' dır. Çeşitli titanyum alaşımlarının kopma dayanıklıı̆ı 700-985 MPa arasındadır. Saf titanyumun uzaması ise yaklaşık \%50 dir. ${ }^{12}$ Saf titanyumun sertliği 160 VHN (Vickers), alaşım ve ısıl işleme tabi tutulmuş titanyumun sertliği 250-500 VHN arasındadır. ${ }^{5}$ Saf titanyumun elastik modülü yaklaşık $15 \times 10^{6} \mathrm{psi}$, alaşım halindeki titanyumun elastik modülü ise $18 \times 10^{6}$ psi dir. $^{5}$ Saf titanyumun germe/akma dayanıklılığı 170-480 $\mathrm{MPa}$, kopma dayanıkılığı 240-550 arasındadır ve saflığına bağlı olarak değişmektedir. ${ }^{22}$ Çeşitli titanyum alaşımlarının germe/akma dayanıklılı̆ı 550-860 MPa arasında değişmektedir. ${ }^{12}$

Vanadyum (V), alüminyum (Al), kalay (Sn), demir (Fe), krom (Cr) ve mangan'ın (Mn) Titanyuma ilavesi ile dirençin arttırıldığı görülmektedir. ${ }^{5,23}$

Yorulmayla çatlak başlamasına en iyi şekilde direnen yapılar küçük a gren büyüklüğü $(<20 \mu \mathrm{m})$, iyi dağıtılmış bir ikinci faz $(\beta)$ ve küçük bir $a / \beta$ ara yüzey alanlı mikro yapılardır ve yüksek sikluslu yorulma dayanıklılı̆ına ( 500-700 MPa) sahiptirler. ${ }^{12}$

Saf titanyumun ISI altında zamana bağlı deformasyon direnci özelliklerinin iyi olmadığı, buna karşın soğuk çalışmalarda bu özelliğinin daha iyileştiği bulunmuştur. $^{5}$

Özellikle karbon olmak üzere nitrojen, oksijen ve hidrojen gibi reaktif gazların kontaminasyonu ile metalin direnci artmakta, çekilebilirliği azalmaktadır. ${ }^{5}$ Metalin direncini arttırılırken aynı zamanda çekilebilirliğinde istenilen seviyede olması için manganez $(\mathrm{Mg})$, alüminyum $(\mathrm{Al})$, vanadyum $(\mathrm{Va})$, Krom (Cr), Kalay (Sn), demir (Fe), ve Molibden (Mo) katılabilir. $^{5}$

Saf titanyum $950{ }^{\circ} \mathrm{C}^{\prime}$ nin üzerinde ısıtılması ve 8 $\mathrm{kg} / \mathrm{cm}^{2}$ lik basınç uygulanması ile plaka halindeki titanyuma şekil verilebilir özellik kazandırılır. Titanyumun bu süperplastisite özelliği sınırlıdır. Bu özelliği sayesinde üst total protezlerin yapımında kullanılabilmektedir. ${ }^{5,23 .}$

Genellikle saf titanyum ve alfa alaşımları çoğunlukla alfa tanelerinden oluşmaktadır. Metalin yorulma dayanım sınırını tane boyutu, oksijen içeriği ve deformasyon sertleşmesinin derecesi değiştirebilir. ${ }^{8}$

\section{Biyolojik özellikleri}

Titanyum titanyumun alerjik reaksiyonlara yol açmaması ve doku cevabının iyi oluşu sebebiyle biyouyumlu bir materyaldir. Biyouyumluğu stabil pasif oksit tabakasına bağlıdır. ${ }^{12,24}$

Titanyumun ağız, vücut ve oda sıcaklığında korozyon direnci ve biyouyumluğu, $1 \mathrm{~nm}\left(10^{-9} \mathrm{~m}\right)^{\prime}$ den daha az kalınlıkta stabil oksit film tabakasının oluşmasıyla önem kazanır. Film tabakasının aşınması durumunda birkaç nanosaniye $\left(10^{-9} \mathrm{sn}\right)$ içinde tekrar oluşur. Oksit film tabakası yüksek sıcaklıkta, kalın olması ve yapışmamış hal almasından dolayı koruyucu değildir. ${ }^{12}$

Titanyum veya alaşımları (Ti6Al4V ve Ti13Nb13Zr) kemik ile osseointegrasyon oluşturur ve kontakta olan dokuların reaksiyonu oldukça ı ıımlıdır. ${ }^{12}$

Lokalize korozyon: Korozyon metal yüzeyindeki çeşitli kimyasal değişikliklere bağlıdır. Titanyumun soğuk işlenmesi, mekanik olarak aşındırılması, freze işlemiyle ortaya çıkan kontaminasyon yüzeyi veya döküm işlemi sırasında bünyesine aldığı kontaminantlar ile lokalize korozyon oluşarak oksit tabakasının koruyucu etkisi azalır. Bu çeşit bozulmalar pitting korozyonu ve çatlak korozyonuna öncülük etmektedir. Ancak bunlar klinikte kullanılan titanyum alaşımlarında nadiren görülmektedir. ${ }^{1,25}$

\section{Titanyum Alaşımları}

Titanyum alaşımları alfa, alfa+beta ve beta olmak üzere üç ana grupta toplanır. Alfa fazındaki titanyum oda sıcaklığında kararlıdır, beta fazındaki titanyum ise yüksek sıcaklıklarda kararlıdır.

\section{Alfa Alaşımları}

Bütün alfa alaşımları iyi bir akma dayancı ve deformasyon direnci, iyi bir dayanıklıık ve yüksek ısılarda oksijen kontaminasyonuna karşı direnç gösterirler. Mekanik özellikleri Tip-3 ve Tip-4 dental alaşımlarınkine benzer. Ancak alfa alaşımları zayıf şekillenme özelliği gösterirler. Sünekliklerini ve toklukluklarını çok düşük sıcaklıklarda dahi korurlar. Isıl işlem ile sertleştirilemezler ve dövülebilme yetenekleri düşüktür. ${ }^{6}$ Alfa alaşımlarına Ti5Al2.5Sn alaşımı örnek olarak verilebilir ve $300^{\circ} \mathrm{C}$ sıcaklığa kadar yüksek çekme ve sürtünme dayanımlarına sahiptir. ${ }^{26}$ 


\section{Alfa + Beta Alaşımları}

Alfa ve beta fazlarının kararlıı̆ını arttıran elementler bu tip alaşımların yapılarında bir arada bulunurlar ve bu iki form arasında özellikler taşırlar Tavlama işleminden sonra dahi çok iyi sünekliğe, homojenliğe ve dayanım özelliği gösterirler. İyi şekil verilebilir ve yüksek ısıda kullanılabilirler. ${ }^{1,9,10,27,28} \mathrm{Bu}$ tip alaşıma Ti6Al4V ve Ti6Al7Nb örnek olarak verilebilir Dental implantlarda kullanılan alaşımlar (Ti6Al4V), genellikle alfa-beta karışımlarıdır. Dental implant materyali için gereken fiziksel ve kimyasal özellikleri ISI ile muamele edildikten sonra kazanırlar. Elastikiyetleri kemik dokusunun elastikliğine diğer herhangi bir implant materyalinkinden daha yakındır. Bu sayede daha iyi stres dağılımı sağlarlar. Hafiftirler, korozyona ve yorgunluğa dirençlidirler. ${ }^{1,4,10}$.

\section{Beta Alaşımları}

Diğer tür alaşımlarile kıyaslandığında daha yüksek sertleşebilirlik, dövülebilirlik ve soğuk şekillendirilebilirlik özelliklerine sahiptirler. Alfa+beta alaşımları ile hemen hemen aynı mukavemet değerlerine, yüksek kırılma dayanımlarına sahiptirler ve korozyon dirençleri molibden ilavesiyle hızla artmaktadır. Sıcakta ve soğukta iyi bir dayanca sahiptirler. Beta stabilizatörleri geçiş elementleri olduğu için alaşımların yoğunluğu fazladır. ${ }^{26}$

\section{Diş hekimliğinde kullanım özellikleri}

Yüksek mekanik dirence ve özgül ağırlığa sahiptir. Bu yüzden yüksek kırılma direnci özelliklerini taşır ve yüksek ısılarda bile bu özelliklerini korurlar. ${ }^{29-31}$

Kimyasal olarak inert ve biyolojik uyumunun oldukça iyi olduğu belirtilmiş̧ir, ancak serbest oksijen ile karşılaşıtıklarında metal yüzeyinde pasif bir oksit tabakası oluşur. Bu tabaka komşu dokulara zarar vermez ve metal ağız içerisinde stabildir. ${ }^{32,33}$ Ağız içindeki bakterilere karşı bakteriostatik rol oynar ve bu etki yüzeydeki oksit tabakasına bağlıdır. ${ }^{32,33}$ İnsan vücudunda $0.2 \mathrm{ppm}$ oranında bulunur. ${ }^{34}$ Hiçbir zaman kanserojen olarak ifade edilmemiştir. ${ }^{35}$ Saf titanyum ve alaşımlarını ilgilendiren herhangi bir alerjik reaksiyondan bahsedilmemiştir. Başarı ile dökümü yapılabilir, dövülebilir ve tel haline getirilebilir, hasta ağzında kaynak yapılabilen tek metal olduğu bildirilmiştir. ${ }^{17,33}$ Korozyona dirençlidir. Metal yüzeyinde oluşan pasif tabaka reaktif titanyumu korozyon ortamından kormaktadir. Herhangi bir pasif metal ile vücutta galvanik korozyon oluşturmadan kullanılabilmektedir. ${ }^{27,30,36}$

\section{Diş hekimliğinde kullanım alanları}

Oral implantolojide implant materyali olarak ${ }^{24,37}$ kullanılmaktadır. Bunun yanı sıra maksillofasial cerrahide plakalar, obtüratör protezlerde metal kaide olarak $^{38}$ vidalar formunda, ${ }^{39}$ ortodontik tellerin ve apareylerin yapımında ${ }^{40}$ endodontide kök kanal postlar. ${ }^{41}$ ve kanal aleti ${ }^{42}$ olarak, konservatif tedavide titanyum pin olarak ${ }^{43}$ pedodontide Titanyum tetraflorür $\left(\mathrm{TiF}_{4}\right)$ topikal kullanımda çürük önleyici olarak, periodontolojide güçlendirilmiş membran olarak ${ }^{44}$ alveolar kemik defektlerini düzeltmede greft materyali ve alloplastik implant materyali olarak, ${ }^{45}$ overdenture protez için tutucu ataçman (flexi-overdenture system) ve metal kaide olarak, kor materyali olarak kullanılan kompozitlerin yapısında ${ }^{46}$ ve titanyumla güçlendirilmiş kompozit simanların yapısında ${ }^{47,48}$ kullanılmaktadır.

Sabit protezlerde, iskelet bölümlü protezlerde ve total protezlerde kullanılmaktadır. Dökümlerinin güç olması, porselenle bağlantısının tartışmalı olması, düşük elastik modülüsüne sahip olması nedeniyle uzun köprülerde kullanımını kısıtlamaktadır ve çift taraflı kullanımının kontrendike olması sabit protez yapımında kullanımını güçleştirmektedir. ${ }^{1,49-51}$

Hareketli bölümlü protezlerde kroşe olarak kullanıldığında daha derin andırkatlara yerleştirilebildiği için destek dişler üzerinde yıkıcı kuvvetler oluşturmamaktadır. Titanyum kroşeler $\mathrm{Cr}$-Co alaşımlardan hazırlanan kroşeler ile kıyaslandığında daha retantiftir. Düşük elastik modülüsü nedeniyle $\mathrm{Cr}$-Co alaşımlardan hazırlanan kroşelere göre titanyum kroşelerin daha kalın hazırlanmalıdır fakat bu da estetik açıdan dezavantaj olabilmektedir. ${ }^{1,52}$ nikel-krom alaşımlarında döküm sonrası ortaya çıkan boyutsal değişikliğin kabul edilen sınırlar içinde olduğu belirtilmiştir. ${ }^{31}$

Akriliğe karşı duyarlıı̆ı olan hastalarda ince titanyum plakaların basınçla şekillendirilmesi ile protezin iç yüzeyi titanyum metalinden yapılabilmektedir. ${ }^{53}$ Titanyum kaide plaklarının polimetilmetakrilatla olan bağlantısının, yüzeyin alümina ile kumlanıp çeşitli yüzey bağlantı ajanları (silan gibi) uygulandıktan sonra arttığı gözlenmiştir. ${ }^{54}$

Titanyum röntgen ışınlarının geçmesine izin verir, bu özelliği ile hem dökümlerin klinik kalitesi değerlendirilebilir, hem de marjinal preparasyon sınııında oluşan veya adeziv restorasyonların altında

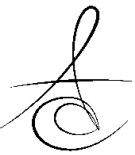


oluşan sekonder çürükler fark edilebilir ve kuronlanan dişin pulpası kolayca kontrol edilebilir. ${ }^{55}$

\section{Titanyumun şekillendirilmesi}

Barlar, bantlar, plakalar ve çekirdekler halinde üretilen titanyumun şekillendirilmesinde kullanılan yöntemler şöyle sıralanabilir:

1. Makine ile aşındırma; freze ya da CAD/CAM.

2. Soğuk şekillendirme; dövme, presleme

3. Isı ile şekillendirme; ısıtılarak form verme, bükme

4. Kaynak

5. Lehim

6. Toz metalurjisi

7. Döküm

8. Kıvılcımla aşındırma (spark erezyon) $)^{1,56-59}$

\section{Döküm}

Titanyum ve alaşımlarının yüksek erime derecelerde erimesi (1660-1672), havayla temasa geçmesi durumunda havadaki Oksijen, Nitrojen ve Hidrojen gibi elementlerle kolaylıkla reaksiyona girmesi nedeni ile okside olması, seramik potayla reaksiyona girmesi, klasik revetman materyalleri ile reaksiyona girmesi, bu metal ve alaşımların klasik döküm yöntemleri kullanarak dökülmesini güçleştirmektedir. ${ }^{20 \text {, }}$

Titanyum dökümlerin elde edilmesindeki en büyük güçlüklerden biri uygun revetman kullanılmasıdır. Titanyum için uygun olan revetman; $1700{ }^{\circ} \mathrm{C}$ gibi yüksek derecelerde bile metal alaşım ile reaksiyona girmeyecek, bu ısılara dayanıklı, soğuma esnasında oluşan büzülmeyi karşılayacak şekilde genleşme gösterebilen ve döküm sonrası metalden kolayca ayrılabilecek bir revetmandır. Hassas titanyum dökümü, döküm sistemi ve revetman materyallerine bağlıdır. $^{60}$ Titanyumun dökümü için geliştirilmiş revetmanlar fosfat bağlı, etil silikat-bağlı ve güçlendirilmiş revetmanlardır. Revetmanın yapısına erimiş titanyumun reaksiyona girmesini engellemek amacı ile refraktör ajanlar olarak bilinen ve titanyumdan daha stabil oksitler oluşturabilen yüksek ısıya ve aşınmaya dirençli silika ( $\mathrm{SiO} 2)$, alümina $\left(\mathrm{Al}_{2} \mathrm{O}_{3}\right)$, magnesia $(\mathrm{MgO})$ ve Zirconia $\left(\mathrm{ZrO}_{2}\right)$ ve kalsiyum gibi oksitler katılmıştır. Titanyum dökümlerde alfa case tabakası kalınlıklarının revetmanların içeriğindeki değişikliklere bağlı olarak farklılık gösterdiği bulunmuştur. ${ }^{12}$
Silika bağlı ve fosfat bağlı revetmanların içeriğindeki elementler ile kimyasal reaksiyona girerek döküm yüzeyinde oldukça sert ve kırılgan bir tabaka meydana gelmesi Titanyumun dökülebilirliliğini kısıtlayan bir problemdir. ${ }^{61}$

İndüksiyon ve elektrik ark yöntemleri Titanyum alaşımlarının eritilmesinde kullanılır. ${ }^{12}$ Yüksek erime derecelerde erimesi ve oksidize olmaya yatkın olmasından dolayı, titanyum özel olarak tasarlanmış döküm makinalarında dökülür. Argon atmosferinde elektrik arkı ile eritme yapan basınç/vakum altında çalışan döküm sistemi, Argon atmosferinde elektrik arkı ile eritme, santrifüj ile döküm yapan sistem, indüksiyon sistemi ile eritme, santrifüj ile döküm yapan sistem olmak üzere 3 tip döküm makinaları bulunmaktadır. ${ }^{62}$

\section{Titanyum porselen bağlantısı}

Konvansiyonel metal-porselen bağlantısında gerekli reaksiyonları sağlamak için yüksek ISI gerekirken titanyum porselen bağlantısı düşük ısılarda sağlanır. Günümüzde uygun titanyum-porselen sistemleri mevcut olmasına rağmen, titanyum-porselen bağlantısı ile ilgili problemler halen tam olarak çözülmüş değildir. ${ }^{11}$

$\mathrm{SiO}_{2}$ - esaslı dental porselenler ve ticari saf titanyum, $720-750{ }^{0} \mathrm{C}^{\prime}$ lik pişirme sıcaklığında belirli sürede temastadır ve titanyumdan oksit tabakaları ayrılır ve takibinde titanyum içinde elementlerin çözünür. Özellikle yüksek ısılarda Titanyumun oksijen ile olan reaktivitesinden dolayı, aşırı oksit formasyonunu önlemek amacıyla seramik fırınlamasının $800{ }^{\circ} \mathrm{C}^{\prime}$ nin altında yapılması gerekir. Titanyumun iç kısımlarında oksijenin çözünmesi \%30, bazen de daha fazla olabilmektedir. Pek çok araştırmada $900{ }^{0} \mathrm{C}$ civarında oksijen difüzyonunun aşırı şekilde artmaya başlayarak daha yüksek ısılarda belirgin hale geldiği vurgulanmışlardır. ${ }^{29,50,63}$ Metal oksit ara yüzeyinde ilk oksit formasyonu oluşur. Çünkü oksijen iyonları içe doğru difüzyon gösterirler. Porselendeki oksitlerin redüksiyonu veya atmosferden porselen tabakasına ve aradaki oksit film tabakasına oksijen difüzyonu sayesinde daha fazla oksidasyon için gerekli olan oksijen atomları elde edilmiş olur. Fırınlama sırasındaki atmosfer ortamı da seramik bağlantısını önemli derecede etkiler. Bu, çevre atmosferden oksijen difüzyonunun oksit formasyonunda önemli bir rolü olduğunu ortaya koyar. Ayrıca fırınlama süresi daha

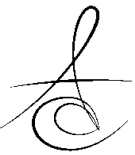


uzun olursa, daha çok oksijen çözünür ve metalseramik ara yüzeyinde stres oluşumuna yol açarak metal-seramik bağlantısının etkilenmesine neden olur. Bunun yanı sıra geleneksel dental alaşımlara (13$14 \times 10^{-6}{ }^{\circ} \mathrm{C}$ ) göre titanyumun ısısal genleşme katsayısı $\left(8.5 \times 10^{-6}{ }^{0} \mathrm{C}\right)$ oldukça düşüktür. Metal seramik restorasyonlarda Isısal genleşme katsayısı önemli rol oynar. Bu sebeple, düşük ısılı ve düşük ısısal genleşme katsayısına sahip özel seramikler gerekmektedir. ${ }^{28}$

Saf titanyum ile seramik arasındaki bağlantı direnci, alfa case tabakasının varlığından olumsuz olarak etkilenmektedir. Bağlantı direnci alfa case tabakasının tamamen uzaklaştıııması ile önemli derecede artmaktadır. Bu tabakanın kısmen bırakılarak seramiğin pişirilmesiyle giderek kalınlaştığı ve kırılmanın çoğunlukla bu bölgeden olduğu belirtilmiştir. Alfa case tabakasının uzaklaştırımasında yalnızca alüminyumoksit ile kumlama güvenli olmadığından sert metal frezleri ile bu tabakanın yüzeyden kaldırıması gerekmektedir. ${ }^{64}$

Titanyum ve düşük ISI porseleni arasındaki bağlantı değeri ile ilgili kaygılar nedeni ile, metal yüzeyine titanyum-seramik kombinasyonunu sağlamak için özel bonding ajan uygulanmıştı. Bonding ajanın oksit tabaka oluşumunu kontrol edip, bağlantı kuvvetini arttırdığını ve bonding ajan içerisinde bulunan titanyum partiküllerinin oksijen inhibitörü olarak rol oynayıp aşırı oksidasyondan yüzeyi koruduğu belirtilmiştir. Bonding ajan yapısını oluşturan titanyum ve seramik partikülleri, ara yüzeyde bağlantıyı sağlayıр, seramik ve titanyum arasındaki ısısal genleşme katsayılarındaki uyumsuzluğu azalttığı bilinmektedir. Bağlantıların mekanik bütünlüğünü Titanyum yüzeyinin morfolojisi etkiler. Porselenlerin, kumlanmış yüzeye elektroliz edilmiş yüzeyden daha iyi bağlandığı belirtilmiştir. $^{63}$

Kumlama işlemi fizikokimyasal bir değişikliktir ve yüzey enerjisini ve ıslanabilirliği etkiler. Titanyum alaşımlarının kumlanması işlemi titanyumun yüzeyindeki düzensizlikleri ve aynı zamanda titanyumun yüzeyinde oluşan oksit film tabakasını da kaldıırak bağlantı dayanıkııı̆ı̆ını etkileyebilir. Metal oksit veya debrisin kaldırıması ve bağlanmayı geliştirmek amacı ile kumlama işlemi uygulanmasında kumlamanın neden olduğu kontaminasyon ve distorsiyon ${ }^{65}$ bir dezavantaj olabilir. ${ }^{66,67}$
Alümina partiküllerinin mevcudiyeti lokal çatlamaya yol açabilir ve stres konsantrasyon noktaları gibi davranarak mekanik bağlantıyı zayıflatabilir. Alümina partikül boyutunun artması titanyum yüzeyinin kontaminasyonunu azalttığı ve yüzey pürüzlülüğünü arttırdığı belirtilmiştir. ${ }^{68}$

\section{Biyouyumluluk}

Diğer olumlu özelliklerinin yanı sıra titanyum ve alaşımlarının diş hekimliği uygulamalarında tercih edilmelerinin en önemli nedeni biyolojik uyumlu olmalarıdır. ${ }^{69}$

Biyouyumluluk bir biyomalzemenin canlı sistemle temas halinde iken önemli olabilecek tüm etkileşmeleri kapsar. Bunlar;

--Kanla teması sırasında biyomateryal pıhtılaşmaya yol açmamalı. Kan hücrelerinde ve kan proteinlerinde geri dönüşümsüz deformasyonlara neden olmamalı.

--Bir biyomalzeme toksik, kanserojen, mutajenik, vb. özelliklere sahip olmamalı ${ }^{70}$

Canlı sistemlerle yüzde yüz uyumlu olan bir biyomateryal henüz mevcut değildir çünkü canlı sistem tarafından tüm biyomalzemeler yabancı cisim olarak algılanmakta ve belirli bir tepkiye yol açmaltadırlar. Bu oluşan tepkinin ılımlı olması ve yan etkilerin canlı sistem tarafından kabul edilebilir olması önemlidir ve geri dönüştürülebilir boyutlarda olmalıdır. ${ }^{70}$

Yapay biyomalzemelerin vücuda ilk girdiği anda yüzeyde organik moleküllerin yerleşmesini sağlayan bir zincir reaksiyonu başlamaktadır. ${ }^{60,71}$

Literatürde titanyum allerjisi bildirilmiştir fakat bu oranın nikel ve krom gibi metal allerjilerine göre görülme sıklı̆ı̆ın daha az olduğu belirtilmiştir. ${ }^{70}$ Birçok çalışmada Titanyum materyallerin diğer metallere göre biyolojik sistem tarafindan daha kolay kabul edilen bir materyal olduğu gösterilmiştir. ${ }^{72,73}$

Maurer ve ark. ${ }^{73}$ vanadyum ve titanyum tuzlarının hücre tarafından alınmasını incelemişler ve titanyumun hücrelerde toksik etki oluşturmadığını fakat vanadyumun $10 \mu \mathrm{g} / \mathrm{ml}$ 'den fazla olduğunda toksik etki gösterdiğini bildirmişlerdir. Titanyumun allerjik reaksiyon meydana getirme potansiyelinin düşük olmuş olması diğer metallere göre titanyumun üstünlüğünü ortaya koymaktadır. 


\section{KAYNAKLAR}

1. Lautenschlager $\mathrm{E}$, Monaghan P. Titanium and titanium alloys as dental materials. Int Dent J 1993;43:245-53.

2. Codel M. Analytical chemistry of titanium metals and compounds. New York, London: Interscience publishers, Inc. 1959, p.3-6.

3. Crawford PR. Titanium. The metal of the gods. NYSDJ. 1994;60:180-1.

4. Palmer JJ. Light Alloys-Metalurgy of the Light Metals. 1981;6:163-208.

5. Jaffee RI, Promisel NE. The science technology and application of titanium. 1st ed., Ozford, Pergamon Pres, 1970.

6. Boyer, Howard E. and Timothy Gai. Metal Handbook. American Society for Metals. Metals park.8th ed, Ohio, gall, 1985

7. Williams DF. Titanium and titanium alloys.In: Biocompatibility of clinical implant materials, ed. By DF Williams, CRC Pres Fld, 1981, p. 9-44.

8. Leyens C. Peters M. Titanium and Titanium alloys, Wiley-VCH, Weinheim, Germany, 2003.

9. Shastry CV, Goldberg AJ. The Influence of drawing parameters on the mechanical properties of two beta titanium alloys.J Dent Res 1983;62:1092-4.

10. Can G, Ersoy E, Aksu LM. Diş Hekimliğinde Maddeler Bilgisi. Özyurt matbacılık, 2014, p. 210-4.

11. Könönen M, Kivikahti J. Fusing of dental ceramics to titanium, J Dent Res. 2001;80:848-54.

12. O'Brien WJ. Dental materials and their selection, 2nd ed, ed by WJ O2Brien, Quintessence Pub Co Inc, Carol Stream , Illinois, 1997.

13. Donley TG, Gillette WB. Titanium endoosseos implant soft tissue interface.: A literature review. J Periodontol 1991;62:153-60.

14. Sundgren JE, Bodö $P$, Lundström I. Auger electron spectroscopic studies of the interface between human tissue and implants of titanium and stainless stell. J Colloid Interf Sci. 1986;110:9-20.

15. Stewart KI, Rudd KD, Kuebker WA. Clinical removable partial prosthodontics 2nd ed. St. Louis,Tokyo: Ishiyaku Euro america Inc. 1992, p. 351-3.

16. Brustone CJ, Goldberg AJ. Beta titanium: a neworthodontic alloy. Am J Orthod 1980;77:12132.
17. Hruska AR. Intraoral welding of pure tianium. Quint International. 1987; 18:683-8.

18. Ulusoy $M$ ve Aydın K. Diş hekimliğinde Hareketli Bölümlü Protezler. Ankara Üniversitesi Diş Hekimliği Fakültesi yayınları,Ankara, 2003.

19. Hamanaka H, Do H, Yoneyama T, Okuno $O$. Dental casting of titanium and $\mathrm{Ni}-\mathrm{Ti}$ alloys by $\mathrm{a}$ new casting machine. J Dent Res 1989;68: 152933.

20. Hero H, Syverud M, Waarli M. mold filling and prosity in casting of titanium. Dent Mater 1993;9:15-8.

21. Johansson B, Bergman B. Corrosion of titanium and amalgam couples. Effect of fluoride, area size, surface preparation and fabrication procedures. Dent Mater 1995;1:41-6.

22. Craig RG. Restorative dental materials, 10th ed, Ed, Mosby year book St. Louis. 1997.

23. Phillips RW. Skinner's Science of dental materials 9th ed, Philadephia, W.B, Saunders Co, 1997.

24. Pohler EM. Unalloyed titaniumfor implants in bone surgery, Injury Int J Care Injured 2002;31:7-13.

25. Parr GR, Gardner LK, Toth RW, Titanium: The mystery metal of implant dentistry. Dental materials aspects. J Prosthet Dent 1985;54:410-4.

26. Ezugwu EO, Wang ZM. Titanium alloys and their machinability , journal of material processing technology 1997;68:262-74.

27. Chern JH, Moser JB, Taira M, Greener EH. Cu-Ti, $\mathrm{Co}-\mathrm{Ti}$ and $\mathrm{Ni}-\mathrm{Ti}$ systems: Corrosion and micrrohardness. J Oral Rehabil 1990;17:383-93.

28. Taira M, Moser JB, Greener EH. Studies oftitanium alloys for dental castings. Dent Mater 1989;5:4550.

29. Adachi M, Mackert JR, Parry EE. Oxide adherence and porcelain bonding to titanium and Ti6Al4V alloy. J DEnt Res 1990;69: 1230-5.

30. Akagi K, Okomoto Y, Matsuura T. Properties of test metal ceramic titanium alloys. J Prosthet Dent. 1992;68:462-7.

31. Blackman R, Barghi NC. Dimensional changes in casting titanium removable partial denture framework. J Prosthet Dent 1991;65:309-15.

32. Lloyd CD. Dental casting alloys: dental materials review: titanium. J Dent 1995 23:77-80.

33. Tooth WR, Rarr GR, Gardner LK. Soft tissue Response to endoosseos titanium oral implants J Prosthet Dent 1985;54:464-7.

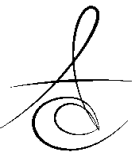


34. Elegli K, Neut C, Romond C. İn-vitro effect of titanium poeder on oral bacteria. Biomaterials 1992;13:25-7.

35. Togaya T, Mashaski S, Tsutsumi S: an appliication of pure titanium to the metal porcelain systems. Dent Mater 1983;2:210-9.

36. Raunhclt G. Corrosion current and PH rise around titanium coupled to dental alloys. Scan J Dent Res 1988;96:466-72.

37. Longoni S, Sartori M, Davide R. A simplified method to reduce prosthetic misfit for a screwretained, implant-supported complete denture using a luting technique and laser weldin, J Prosth Dent. 2004;91:595-8.

38. Rilo B, da Silva JL, Martinez-Insua A, Santana U. A titanium and visible light polymerized resin obturator, J Oral Rehabil 1997;24:338-41.

39. Ismailoğlu K, Coskunfirat OK, Tetik G, Ozgentas HE. Complication and removable rates of miniplates and screws used for maxillofacial fractures. Ann Plast Surg 2002;4883:265-8.

40. Walker MP, White RJ, Kula KS. Effect of fluride prophylactic agents on the mechanical properties of nickel-titanium-based orthodontic wires, Am j Orthod Dentofacial Orthop 2005 127:662-9.

41. GotoY, Nicholls JI, Phillips KM, Junge T. Fatigue resistance of endodontically treated teeth restored with three dowel-and-core systems, J Prosthet Dent 2005;93:45-50.

42. Rangel S, Cremonese R, Bryant S, Dummer P. Shapping ability of race rotary nickel-titanium instruments in stimulated root canals. J Endod 2005;31:460-3.

43. Šegovic S, Ferk S, Anic I, Jukic S, Galic N, Sistig S. Changes in dentin after insertion of self-threaading titanium-reinforced compos,te cement. J Prosthet Dent 1992;68:910-2.

44. Cortellini $P$, Tonetti Ms. Clinical performance of a regenerative strategy for intrabony defects: scientific evidence and clinical exxperience, J Periodontol 2005;76:341-50.

45. Stevenson GC, Connely ME. Titanium palate maxillary overdenture: a clinical report, J Prosthodont 1992;1:57-60.

46. Cohen BI, Pagnillo MK, Newman I, Musikant BL, Deutsch AS. Effects of three bonding systems on the torsionel resistance of titanium-reinforced composite cores supported by two post designs. ]
Prosthet Dent 1999;81:678-83.

47. Cohen BI, Condos S, Musikant BL, Deutsch AS. Retentive properties of threaded splint-shaft posts with titanium-reinforced composite cement. J Prosthet Dent 1992;68:910-2.

48. Nissan J, Dmitry Y, Assif D. The use of reinforced composite resin cement as compensation for reduced post length. J Prosthet Dent 2001;86:3048.

49. Walter M, Böning K, Repel PD, Freesmeyer WB. Six-year follow-up of titanium and high-gold porcelain-fused-to-metal fixed partial dentures ] Oral Rehabil 1999;26:91-6.

50. Hautanıemı JA, Hero $H$,.on the bonding of porcelain on titanium. J Material Science 1992;3:186-91.

51. Kaus T, Pröbster $L$, Weber $H$. Clinical follow-up study of ceramic veneered titanium restorationsthree-year results. Int J Prosthodont;1996;9:9-15.

52. Au AR, Lechner SK, Thomas CJ, Mori T, Chung P. Titanium for removablepartial dentures (III): 2year clinical follow-up in an undergraduate programme. J Oral Rehabil 2000;27:978-84.

53. Mori T, Togaya T, Jean-Louis M, Yabugami $M$. titanium for removable dentures. I. Laborarory procedures, J Oral rehabil 1997;24:338-41.

54. May KB, Fox J, Razzoog ME, Lang BR. Silane to enhance the bond between polymethyl metacrylate and titanium. J Prosthet Dent 1995;73: 428-31.

55. Leinfelder KF, Lemons JE, Clinical restorative materials and techniques. Philadephia. Lea\&Febiger, 1988, p. 251-67.

56. Rekow Ed: Dental CAD-CAM Systems. What is the State of art? JADA 1991;122:43-8.

57. Brick RM, Rense AW, Gordon RB. Structure and properties of engineering material 4th ed. Mc Grawn Hill Inc., Tokyo, 1977.

58. Cernavin I, Pugatschew A, Boer N, Tyas MJ. Laser applications in dentistry: A review of the literature. Aust Dent J. 1994;39:28-32.

59. Razzoog ME, Lang BR, Russel MM, May KB. Comparison of the color stability of convantional and titanium dental porcelain. J Prosthet Dent 1994;72:453-6.

60. Hung CC, Hou GL, Tsai CC, Huang CC. Pure titanium casting into zirconia-modified magnesiabased investment molds. 2004;20:846-51.

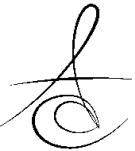


61. Ohkubo C, Watanabe I, Ford JP, Nakajıma H, Hosol T, Okabe T. The machinability of cast titanium and Ti6Al4V. Biomaterials 2000;21:421-8.

62. Zinelis S, Tsetsekou A, Papadopoulos T. Thermal expansion and microstructural analysis ofexperimental metal-ceramic titanium alloys. J Prosthet Dent;2003;90:332-8.

63. Kimura H, Horgn C, Okazaki M, Takashi J. Oxidation effects on porcelain-titanium interface reactions and bond strengths. Dent Mater 1990;9:91-9.

64. Tesch U, Passler K, Mann E. Untersuchungen zum titan-keramik verbund, dental labor, 1993;41:71-4.

65. Peutzfeldt A, Asmussen E. Distortion of alloy by sandblasting, Am J Dent 1996;9:65-6.

66. Kern M, Thompson VP. Effect of stanblasting and silica coating procedures on puretitanium. J Dent 1994;22:300-6.

67. LimBS, Heo SM, Lee YK, Kim CW. Shearbond strength between titanium alloys and composite resin: standbalsting versus fluorid-gel treatment, ] Biomed Mater Res B Appl Biomater. 2003;64:3843.

68. Papadopoulos T, Tsetsekou A, Eliades G. Effect of aluminium oxide sandblasting on cast commercially pure titanium surfaces. Eur J Prosthodont Restor Dent. 1999;7:15-21.

69. Uzun IH. Bayındır F. Dental uygulamalarda titanyum ve özellikleri. Atatürk Üniv Diş Hek Fak Derg 2010;20: 213-20.

70. Boretos, J., M. Eden, and Y. Fung, Contemporary Biomaterials: Material and Host Response, Clinical Applications, New Technology and Legal Aspects. J Biomecha Eng, 1985;107:87.

71. Maurer AM, Merritt K, Brown SA. Cellular uptake of titanium and vanadium from addition of salts or fretting corrosion in vitro. J Biomed Mater Res 1994;28:241-6.

72. Kudelska-Mazur D, Lewandowska-Szumiez M, Komender J. Human osteoblast in contact with various biomaterials in vitro. Ann Transplant 1999;4:98-100.

73. Schmidt C, Ignatius AA, Claes LE. Proliferation and differentiation parameters of human osteoblasts on titanium and steel surfaces. J Biomed Mater Res 2001;54:209-15.

\author{
Yazışma Adresi \\ Doç. Dr Perihan Oyar \\ Hacettepe Üniversitesi \\ Sağlık Hizmetleri Meslek Yüksek Okulu, Diş- \\ Protez Teknolojisi Programı, \\ D-Blok, 3. Kat, 06100 Sinhıye-Ankara / \\ TÜRKİYE, \\ Fax: $+90-312-3102730$ \\ telefon: +90-312-305 1587 / 111, \\ e-mail: poyar73@gmail.com
}

